\title{
The Cost of Growing Older: Challenges for European Pension Systems
}

Pension reform has been on the agendas of many European policymakers for the better part of the last three decades. While some EU countries have made sweeping reforms several years ago, others are currently in the process. Undoubtedly, most will need to re-evaluate their systems due to the coronavirus crisis, at least temporarily. With Europe's ageing populations, declining fertility rates and increasing life expectancy, the associated rise in the old-age dependency ratio puts strain on unfunded, pay-as-you-go pension systems. This implicit pension debt has important macroeconomic implications. Often politically controversial and subject to intense policy debate, pension reforms may reduce entitlements for some demographic groups of the population. This has lead to widespread public dissatisfaction among the affected groups. It is necessary to look at a country's history and key features of its pension system in order to understand the related policy discussion. This Forum analyses the effects of different pension arrangements - with a focus on the challenges, history and demographics of Finland, France, Germany and Italy - on labour markets, on national growth, and on the distribution of burdens and benefits.

Pension Systems in the EU - Some Policy Issues

Mikkel Barslund, Centre for European Policy Studies, Brussels, Belgium.

Lessons From Italy: A Good Pension System Needs an Effective Broader Social Policy

Framework

Daniele Franco, Bank of Italy, Rome, Italy.

Pietro Tommasino, Bank of Italy, Rome, Italy.

Towards a Universal Pension Points System in France

Hervé Boulhol, Organisation for Economic Co-operation and Development, Paris, France.

They Will Definitely Need Us, When We Are 64: Old-Age Provision in Germany

Martin Werding, Ruhr-University Bochum; and CESifo Research Network, Munich, Germany.

The Finnish Pension System and Its Future Challenges

Tarmo Valkonen, ETLA Economic Research, Helsinki, Finland. 